\title{
PENGARUH MUTASI, PROMOSI DAN BUDAYA ORGANISASI TERHADAP KINERJA PEGAWAI KANTOR KEMENTERIAN AGAMA KOTA BANJARBARU
}

\author{
Taufiqurrahman Noor \\ Kantor Kementerian Agama Kota Banjarbaru \\ J1. Panglima Batur No. 6; Kota Banjarbaru \\ e-mail: taufiqurrahmannoor@gmail.com
}

\begin{abstract}
This study aims to identify the effect of mutation, promotion and cultural organization towards employees' performance of Religious Affairs Office in Banjarbaru City. The research method is quantitative method. There are 164 population and 116 samples. The analysis technique is multiple linear regressions. The results of this study indicate that the variable mutations, promotion and cultural organization have partial and simultaneous influence on employees' performance of Religious Affairs Office in Banjarbaru City. The dominant variable which affect on employees' performance is promotion.
\end{abstract}

Keywords: mutation, promotion, organizational culture, performance

\begin{abstract}
Abstrak: Penelitian ini bertujuan untuk mengetahui pengaruh mutasi, promosi dan budaya organisasi terhadap kinerja pegawai Kantor Kementerian Agama Kota Banjarbaru. Metode yang digunakan dalam penelitian ini adalah metode kuantitatif. Populasi berjumlah 164 dan sampel 116. Teknik analisis data dengan menggunakan regresi linear berganda. Hasil penelitian ini menunjukkan bahwa mutasi, promosi dan budaya organisasi berpengaruh berpengaruh secara parsial dan simultan dan terhadap kinerja pegawai Kantor Kementerian Agama Kota Banjarbaru. Variabel yang berpengaruh dominan terhadap Kinerja Pegawai adalah promosi.
\end{abstract}

Kata kunci: mutasi, promosi, budaya organisasi, kinerja

\section{Latar Belakang}

Salah satu bentuk dari pengembangan terhadap pegawai negeri sipil adalah mutasi sebagai penjelmaan/perwujudan dari dinamika organisasi yang dijadikan sebagai salah satu cara untuk mencapai tujuan organisasi.

Mutasi tidak terlepas dari alasan untuk mengurangi rasa bosan pegawai kepada pekerjaan serta meningkatkan motivasi dan kinerja pegawai serta untuk memenuhi keinginan pegawai sesuai dengan minat dan bidang tugasnya. Meskipun begitu, dalam pelaksanaannya mutasi kerja sering disalahtafsirkan orang yaitu sebagai hukuman jabatan atau didasarkan atas hubungan baik antara atasan dengan bawahan. Pelaksanaan mutasi harus benar-benar berdasarkan penilaian yang objektif dan didasarkan atas indeks prestasi yang dicapai oleh pegawai, mengingat sistem pemberian mutasi dimaksudkan untuk memberikan peluang bagi para pegawai negeri sipil (PNS) dalam mengembangkan potensi yang dimilikinya.

Salah satu cara yang dapat ditempuh oleh manajemen untuk meningkatkan kinerja para pegawainya adalah dengan melakukan promosi jabatan bagi pegawai yang mampu memberikan prestasi kerja lebih di satu pihak dan memberikan tindakan disiplin sesuai dengan ketentuan yang berlaku bagi mereka yang tidak mampu melaksanakan kewajibannya sesuai dengan tanggung jawabnya di lain pihak. Menurut Nitisemito (2005:177), promosi jabatan adalah proses pemindahan pegawai dari suatu jabatan ke jabatan lain yang lebih tinggi.

Dalam membuat keputusan promosi, dibutuhkan berbagai pertimbangan. Apabila 
terdapat keputusan yang salah dalam melaksanakan promosi jabatan. Hal ini akan menimbulkan efek samping yang tidak baik bagi pegawai dan organisasi, selanjutnya, dapat mengakibatkan kinerja para pegawainya menurun sehingga harapan organisasi untuk meningkatkan produktivitas tidak akan tercapai. Untuk menghindari efek negatif tersebut, pimpinan organisasi hendaknya melakukan penilaian terhadap pegawai yang akan dipromosikan dengan seobjektif mungkin berdasarkan standar yang telah ditetapkan.

Apabila kondisi tersebut terjadi dalam implementasinya, maka kecenderungan adanya ketidakpuasan atas keputusan yang diambil oleh manajemen dari pihak-pihak yang berada di internal organisasi akan dapat diminimalisir, kerena keputusan yang dibuat organisasi dipandang sudah tepat. Dengan dilaksanakannya promosi jabatan secara tepat dalam organisasi, maka diharapkan kinerja pegawai akan semakin meningkat.

Promosi memberikan peran penting bagi setiap pegawai, bahkan menjadi idaman yang selalu dinantikan. Dengan promosi, berarti ada kepercayaan dan pengakuan mengenai kemampuan serta kecakapan pegawai bersangkutan untuk menduduki suatu jabatan yang lebih tinggi. Dengan demikian, promosi akan memberikan status sosial, wewenang, tanggung jawab, serta penghasilan yang semakin besar bagi pegawai. Promosi jabatan merupakan usaha yang dilakukan oleh Kantor Kementerian Agama Kota Banjarbaru untuk meningkatkan kinerja para pegawainya. Walaupun kebijakan tersebut telah ditetapkan, namun pegawai Kantor Kementerian Agama Kota Banjarbaru belum menunjukkan kinerja yang maksimal.

Organisasi yang memiliki budaya akan mampu bertahan melewati sejumlah tantangan yang muncul dalam berbagai masa. Usaha untuk menanamkan dan memperkuat budaya organisasi antara lain menyusun desain mutasi dan promosi, menyusun prosedur dan sistem organisasi, mendesain ruang fisik dan bangunan kantor, menanamkan sejarah, legenda, mitos dan kejadian kejadian tertentu, orang-orang penting serta pernyataan formal menyangkut filosofi organisasi. Budaya organisasi yang ada mengacu pada rumusan keyakinan (belief), nilai-nilai (value) dan cara bel- ajar dari pengalaman yang dibangun sepanjang sejarah organisasi yang dimanifestasikan dalam tiap pengaturan materi dan perilaku tiap anggota organisasi tersebut atau nilainilai yang menjadi pegangan.

Kantor Kementerian Agama Kota Banjarbaru merupakan instansi pemerintahan di lingkungan Kementerian Agama Republik Indonesia yang dalam pekerjaannya membidangi keagamaan di Kota Banjarbaru, dan memiliki Kantor Urusan Agama, sekolah tingkat mandrasah, tsanawiyah dan aliyah. Berdasarkan pada penjelasan tersebut, maka diperlukan pengkajian emperis yang berkaitan dengan pengaruh mutasi, promosi dan budaya organisasi terhadap kinerja pegawai Kantor Kementerian Agama Kota Banjarbaru.

\section{Studi Literatur}

Tujuan perusahaan dapat dicapai dengan sempurna apabila tenaga kerja diberikan kesempatan dalam mengembangkan karier dan meningkatkan kemampuan kerja terutama melalui mutasi personal yang tepat. Dengan mutasi personal yang tepat, karyawan akan termotivasi untuk meningkatkan kualitas kerjanya karena hal ini merupakan suatu tantangan untuk mereka sehingga keefektifan dalam bekerja dapat tercapai. Dengan adanya mutasi, diharapkan dapat terjadi hubungan yang cocok antara karyawan dan jabatan (the right man in the right place), sehingga karyawan dapat bekerja secara efisien dan efektif pada jabatan itu. Pada dasarnya, mutasi termasuk dalam fungsi pengembangan pegawai, karena tujuannya adalah untuk meningkatkan efisiensi kerja dalam organisasi.

Menurut Hasibuan (2007:103), mutasi adalah suatu perubahan posisi/jabatan/tempat/pekerjaan yang dilakukan baik secara horizontal maupun vertikal di dalam satu organisasi. Sastrohadiwiryo (2008:9) mengemukakan bahwa rotasi jabatan adalah kegiatan ketenagakerjaan yang berhubungan dengan proses pemindahan fungsi, tanggung jawab dan status ketenagakerjaan tenaga kerja ke situasi tertentu dengan tujuan agar tenaga kerja yang bersangkutan memperleh kepuasan kerja yang mendalam dan memberikan 
prestasi kerja yang semaksimal mungkin kepada perusahaan.

Menurut Hasibuan (2007:104), sebabsebab mutasi digolongkan atas permintaan sendiri (personel transfers) dan alih tugas produktif (production transfers). Dale Yoder (Moekijat, 2005:109) membedakan dua macam pemindahan berdasarkan sebab-sebab pemindahan itu sendiri, yakni personal transfer dan production transfer.

Mutasi atas permintaan sendiri adalah mutasi yang dilakukan atas keinginan sendiri dari karyawan yang bersangkutan dan dengan mendapat persetujuan pimpinan organisasi. Sementara itu, alih tugas produktif adalah mutasi karena kehendak pimpinan perusahaan untuk meningkatkan produksi dengan menempatkan karyawan bersangkutan ke jabatan atau pekerjaan yang sesuai dengan kecakapannya.

Simamora (2006:640) mengutarakan pendapat lain tentang sebab terjadinya mutasi, di antaranya adalah karyawan dengan riwayat kinerja yang rendah; praktik penempatan karyawan keliru; dan tidak puas dengan pekerjaan sekarang.

Menyoroti pembahasan di atas, dapat disimpulkan bahwa secara umum penyebab mutasi ada dua hal. Pertama yaitu permintaan pegawai yang bersangkutan itu sendiri. Hal ini dapat disebabkan oleh ketidakpuasan pegawai terhadap posisi/jabatan atau tempat pekerjaannya, ketidakcocokan pekerjaan yang tidak sesuai dengan kemampuan yang ia miliki. Penyebab yang kedua adalah keputusan organisasi atau perusahaan yang bersangkutan. Hal ini dikarenakan instansi tersebut perlu melakukan reorganisasi atau perputaran jabatan/posisi untuk menghindari kejenuhan yang dirasakan oleh pegawai.

Promosi merupakan suatu masalah yang penting, bukan saja dalam hal memilih atau penempatan orang yang tepat pada tempat yang tepat tetapi juga merupakan dorongan bagi atasan untuk merencanakan suatu kebijakan di dalam bidang personalia dalam memfasilitasi bawahan untuk mengembangkan diri sampai dapat berprestasi.

Menurut Saydam (2005:550), promosi merupakan perubahan pekerjaan atau status/ jabatan karyawan dari tingkat yang lebih rendah ke tingkat yang lebih tinggi. Menurut Suwatno (2007:97), promosi merupakan pemberian tugas, tanggung jawab, serta wewenang baru pada seorang karyawan yang lebih besar dan baik dan diikuti pula oleh kenaikan upah yang lebih tinggi dari semula karena adanya kenaikan pangkat dan jabatan. Menurut Rivai. (2005:211), promosi terjadi apabila seorang karyawan dipindahkan dari satu pekerjaan ke pekerjaan lain yang lebih tinggi dalam pembayaran, tanggung jawab dan atau level. Dari beberapa pendapat para ahli tersebut dapat disimpulkan bahwa promosi adalah proses pemindahan pegawai dari jabatang yang lebih rendah ke jabatan yang lebih tinggi yang akan memberikan status sosial, wewenang, tanggung jawab serta penghasilan yang semakin besar bagi pegawai tersebut.

Manajemen hendaknya memberikan informasi yang jelas tentang dasar pertimbangan seorang pegawai untuk dipromosikan. Hal ini sangat penting agar pegawai mengetahui dan dapat memperjuangkan apa yang menjadi haknya.

Setiap organisasi mempunyai dasar yang beda dalam menentukan promosi. Menurut Saydam (2005:102) dasar promosi antara lain sebagai berikut ini.

1. Promosi berdasarkan prestasi kerja

2. Promosi berdasarkan senioritas

3. Promosi berdasarkan prestasi dan senioritas.

Seperti yang diungkapkan Hasibuan (2007:109) bahwa dasar promosi jabatan adalah sebagai berikut ini.

1. Pengalaman (senioritas), yaitu promosi yang didasarkan pada lamanya pengalaman kerja karyawan. Kebaikannya adalah penghargaan dan pengakuan bahwa pengalaman merupakan sesuatu hal yang berharga. Dengan pengalaman, seseorang dapat mengembangkan kemampuannya sehingga karyawan lebih betah bekerja di perusahaan dengan harapan suatu waktu ia akan dipromosikan. Keburukannya adalah seorang karyawan yang kemampuannya sangat terbatas, tetapi karena sudah lama bekerja tetap dipromosikan.

2. Kecakapan, yaitu promosi berdasarkan penilaian kecakapan. Kecakapan terdiri atas sebagai berikut: 
a. kecakapan dalam pelaksanaan prosedur kerja yang praktis, teknik-teknik khusus dan disiplin ilmu pengetahuan;

b. kecakapan dalam menyatukan dan menyelaraskan bermacam-macam elemen yang semuanya terlibat dalam penyusunan kebijaksanaan dan dalam situasi manajemen;

c. kecakapan dalam memberikan motivasi secara langsung; dan

d. kombinasi antara pengalaman dan kecakapan.

3. Kombinasi pengalaman dan kecakapan, yaitu promosi berdasarkan pada lamanya dinas, ijazah pendidikan formal yang dimiliki, hasil ujian kenaikan golongan. Pengalaman dan kecakapan sama-sama penting. Dengan pengalaman seseorang lebih banyak mengetahui cara-cara dalam menyelesaikan berbagai masalah dan lebih matang emosinya dalam mengambil keputusan.

Schein dari MIT, dalam Armstrong (2005:87) menyatakan bahwa budaya perusahaan sebagai pola asumsi dasar yang ditemukan oleh kelompok tertentu, ditemukan atau dikembangkan untuk mempelajari cara mengatasi masalah-masalah adaptasi dari luar dan cara berintegrasi yang telah berfungsi dengan baik atau dianggap berlaku. Oleh karena itu, budaya organisasi harus diajarkan kepada para anggota baru sebagai yang benar untuk mengundang, memikirkan, dan merumuskan masalah-masalah ini.

Selanjutnya, Robbins (2006:112) menyatakan bahwa budaya organisasi sebagai suatu sistem makna bersama yang dianut oleh anggota-anggota yang membedakan organisasi tersebut dengan organisasi lain.. Lebih lanjut, Robbins (2006:123) menyatakan bahwa sebuah sistem pemaknaan bersama dibentuk oleh warganya yang sekaligus menjadi pembeda dengan organisasi lain. Sistem pemaknaan bersama merupakan seperangkat karakter kunci dari nilai-nilai organisasi.

Memahami budaya organisasi: Budaya organisasi adalah norma-norma dan kebiasaan yang diterima sebagai suatu kebenaran oleh semua orang dalam organisasi. Budaya organisasi menjadi acuan bersama antara manusia dalam melakukan interaksi dan organi- sasi. Pendapat lain dikemukakan Susanto (2007:86) yang menyatakan bahwa budaya organisasi adalah sebagai nilai-nilai yang menjadi pedoman sumber daya manusia untuk menghadapi permasalahan eksternal dan usaha penyesuaian integrasi ke dalam perusahaan sehingga masing-masing anggota organisasi harus memahami nilai-nilai yang ada dan bagaimana mereka harus bertindak dan berperilaku.

Kotter dan Hesket dalam Soetjipto (2007:54) berpendapat bahwa budaya organisasi pada dasarnya merupakan norma-norma dan nilai-nilai yang berlaku dalam organisasi, contohnya kesigapan dalam memberikan pelayanan kepada para pelanggan, sedangkan nilai mencerminkan keyakinan atau kepercayaan mereka akan hal-hal tertentu yang mampu mendatangkan kesuksesan, contohnya perhatian yang besar kepada kepuasan pelanggan. Jika keduanya dibandingkan, norma relatif lebih kasat mata dan lebih mudah untuk dirubah.

Hofstede (2007:99) menyatakan bahwa budaya organisasi sebagai konstruksi dari dua tingkat karakteristik, yaitu karakteristik organisasi yang kelihatan (observable) dan yang tidak kelihatan (unobservable). Pada level observable, budaya organisasi mencakup beberapa aspek organisasi seperti arsitektur, seragam, pola perilaku, peraturan, bahasa, dan seremoni yang dilakukan perusahaan. Sementara itu, pada level (unabsorvable), budaya organisasi mencakup shared value, norma-norma, kepercayaan, asumsiasumsi para anggota organisasi untuk mengelola masalah dan keadaan-keadaan sekitarnya.

Perusahaan yang berorientasi pada kepentingan pasar memerlukan budaya dukungan (support culture) dan budaya prestasi (achievement culture) sebagai cara meningkatkan motivasi dan komitmen karyawan. Budaya organisasi yang efektif adalah budaya organisasi yang mengakar kuat dan dalam. Di perusahaan yang berbudaya demikian, hampir semua individunya menganut nilainilai yang seragam dan konsisten.

Setiap organisasi atau bahkan setiap bagian dalam suatu organisasi menunjukkan simbol dan ritual yang berbeda karena di dalamnya terdiri dari berbagai individu dengan 
latar belakang dan pengalaman yang beragam. Namun demikian, budaya organisasi memiliki sejumlah disemsi yang berguna untuk memudahkan setiap upaya pengidentifikasian karakteristik budaya tertentu dalam organisasi. Hofstede (2007:75) menyatakan bahwa ada enam dimensi budaya organisasi yang dapat ditemukan pada berbagai organisasi, yaitu sebagai berikut ini.

1. Process-oriented versus resuls-oriented. Organisasi dengan budaya berorientasi pada proses ditandai dengan karyawan yang bekerja di dalamnya cenderung memperhatikan pada proses kegiatan dan bukan pada pencapaian hasil, menghindari risiko, tidak berusaha dengan keras, dan berpendapat bahwa setiap hari esok yang akan dialaminya bermakna sama dengan hari-hari sebelumnya tanpa perubahan tantangan. Sebaliknya, pada budaya organisasi yang berorintasi pada hasil, karyawan cenderung memusatkan perhatiannya pada pencapaian hasil terlepas dari proses atau kegiatan yang dilakukannya, merasa nyaman dengan situasi yang berbeda atau menantang, selalu berusaha secara maksimal, dan menganggap bahwa datangnya hari esok akan membawa tantangan tersendiri yang berbeda dengan hari-hari atau waktu sebelumnya. Dengan konteks yang demikian ini, budaya organisasi dengan orientasi orientasi pada hasil merupakan strong culture atau budaya yang positif.

2. Employee-oriented versus job-oriented. Dalam organisasi yang berorientasi pada employee, karyawan merasa bahwa masalah-masalah personel mereka pada dasarnya adalah masalah organisasi juga di mana pimpinan harus bertanggung jawab dalam mengatasi masalah kesejahteraan individu dan keluarganya, sementara dalam pengambilan keputusan organisasi cenderung melibatkan banyak pihak atau komunal. Sebaliknya, dalam organisasi yang berorientasi pada job, karyawan merasakan adanya tekanan yang kuat untuk menyelesaikan semua pekerjaan, sementara proses pengambilan keputusan dilakukan secara invidual.

3. Parochial versus professional. Pengenalan terhadap organisasi yang berbudaya paro- chial dapat ditentukan melalui perasaan karyawan dalam hal ikut memiliki organisasi (employee's belonging to the organization). Sementara itu, dalam organisasi berbudaya profesional, faktor profesionalisme karyawan merupakan penentu utama sebagai identitas organisasi. Perbedaan utama dari karyawan yang parochial dan karyawan yang profesional dapat diketahui dari jawaban yang diberikan atas pertanyaan,"Apa yang anda kerjakan?" Seorang karyawan parochial akan menjawab,"Saya bekerja untuk perusahaan X." Sementara karyawan professional akan menjawab, "Saya adalah seorang insinyur."

4. Open system versus closed system. Karyawan dalam organisasi dengan sistem terbuka merasa bahwa organisasi dan semua karyawannya bersikap terbuka dan mau menerima terhadap hadirnya pendatang/ pegawai baru dan pihak-pihak eksternal lainnya, semua pihak merasa ada kesesuaian dengan nilai-nilai organisasi, serta karyawan baru tidak memerlukan waktu yang lama untuk menyesuaikan diri dengan organisasi. Dalam organisasi dengan budaya sistem tertutup, interaksi antara karyawan cenderung tertutup dan rahasia, hanya orang-orang atau pihak tertentu yang merasa cocok atau sesuai dengan nilai-nilai organisasi, sementara bagi karyawan baru membutuhkan waktu yang lama untuk menyesuaikan diri dengan keadaan organisasi.

5. Tight control versus loose control. Pengendalian yang ketat ditunjukkan dengan adanya kesadaran setiap individu terhadap pentingnya makna efisiensi (cost-conscious), cenderung tepat waktu dalam pekerjaan dan penyelesaiannya dan karyawan bersikap serius tentang organisasi dan pekerjaannya. Adapun dalam organisasi yang berbudaya pengendalian longgar menunjukkan tidak adanya pihak yang menyadari makna pentingnya tentang biaya (cost), bekerja tidak sesuai dengan jadwal penyelesaian, dan banyak menggelar jokes tentang organisasi dan pekerjaannya.

6. Pragmatic versus normative emphasis towards clients. Organisasi dengan budaya pragmatis memiliki ciri khusus yaitu ter- 
dapat penekanan utama pada pemenuhan kebutuhan pelanggan di mana hasil yang dicapai merupakan pertimbangan yang lebih penting daripada sekedar suatu pelaksanaan prosedur yang benar. Organisasi seperti ini juga bersifat fleksibel dalam menyikapi etika dalam bisnis. Sebaliknya organisasi dengan budaya normatif di dalamnya terdapat upaya keras untuk mematuhi prosedur dengan benar dan menganggapnya lebih penting daripada pencapaian hasil, sementara terhadap etika organisasi memiliki standar tinggi yang dipakai sebagai acuan. Dimensi keenam dalam budaya organisasi ini utamanya berkaitan dengan topik terkini dalam bisnis yaitu tentang orientasi perusahaan pada pelanggan. Perusahaan yang berbeda pada tekanan kompetensi yang ketat cenderung berbudaya pragmatis, sebaliknya organisasi yang bersifat monopolistis di mana tidak terdapat persaingan dalam bisnis cenderung bersifat normatif.

Berdasarkan pengertian-pengertian di atas, budaya organisasi dapat dikatakan sebagai aturan main yang ada dalam perusahaan yang akan menjadi pegangan dari sumber daya manusia (SDM) dalam menjalankan kewajibannya dan nilai-nilai untuk berperilaku dalam organisasi. Nilai-nilai tersebut tercermin dalam perilaku dan sikap mereka seharihari selama mereka berada dalam organisasi tersebut dan sewaktu mewakili organisasi berhadapan dengan pihak luar, Dengan kata lain, budaya organisasi mencerminkan cara karyawan melakukan sesuatu (membuat keputusan, melayani orang, dsb.). Misalnya, cara petugas penerima tamu, kondisi ruangan, pakaian seragam, cara menerima telepon, dan sebagainya.

Robbins (2006:132) menyatakan ada 10 karakteristik yang apabila dicampur dan dicocokkan, dengan budaya organisasi. Kesepuluh karakteristik budaya organisasi tersebut sebagai berikut ini.

1. Inisiatif individual, adalah tanggung jawab, kebebasan atau independensi yang dipunyai setiap individu dalam mengemukakan pendapat. Inisiatif individu tersebut perlu dihargai oleh kelompok atau pimpinan suatu organisasi sepanjang me- nyangkut ide untuk memajukan dan mengembangkan organisasi/ perusahaan.

2. Toleransi terhadap tindakan berisiko. Dalam budaya organisasi perlu ditekankan, sejauh mana para pegawai dianjurkan untuk dapat bertindak agresif, inovatif, dan mengambil resiko. Suatu budaya organisasi dikatakan baik, apabila dapat memberikan toleransi kepada anggota para pegawai untuk dapat bertindak agresif dan inovatif untuk memajukan organisasi/ perusahaan serta berani mengambil risiko terhadap apa yang dilakukannya.

3. Pengarahan, dimaksudkan sejauh mana suatu organisasi/perusahaan dapat menciptakan dengan jelas perusahaan dan harapan yang diinginkan. Sasaran dan harapan tersebut jelas tercantum dalam visi, misi, dan tujuan organisasi. Kondisi dapat berpengaruh terhadap kinerja organisasi/ perusahaan.

4. Integrasi, dimaksudkan sejauh mana suatu organisasi/perusahaan dapat mendorong unit-unit organisasi untuk bekerja dengan cara yang terkoordinasi. Kekompakan unit-unit organisasi dalam bekerja dengan cara yang terkoordinasi. Kekompakan unit-unit organisasi dalam bekerja dapat mendorong kualitas dan kuantitas pekerjaan yang dihasilkan.

5. Dukungan manajemen, dimaksudkan sejauh mana para manajer dapat memberikan komunikasi atau arahan, bantuan serta dukungan yang jelas terhadap bawahan (karyawan) sangat membantu kelancaran kinerja suatu organisasi/perusahaan.

6. Kontrol, alat kontrol yang dapat dipakai adalah peraturan-peraturan atau normanorma yang berlaku dalam suatu organisasi atau perusahaan. Untuk itu diperlukan sejumlah peraturan dan tenaga pengawas (atasan langsung) yang dapat digunakan untuk mengawasi dan mengendalikan perilaku pegawai/karyawan dalam suatu organisasi.

7. Identitas, dimaksudkan sejauh mana para anggota/karyawan suatu organisasi/perusahaan dapat mengidentifikasikan dirinya sebagai satu kesatuan dalam perusahaan dan bukan sebagai kelompok kerja tertentu atau keahlian professional tertentu. Identitas diri sebagai satu kesatuan da- 
lam perusahaan sangat membantu manajemen dalam mencapai tujuan dan sasaran organisasi/perusahaan.

8. Sistem imbalan, dimaksudkan sejauh mana alokasi imbalan (seperti kenaikan gaji, promosi, dan sebagainya) didasarkan atas prestasi kerja pegawai, bukan sebaliknya didasarkan senioritas, sikap pilih kasih, dan sebagainya. Sistem imbalan ang didasarkan atas prestasi kerja pegawai dapat mendorong pegawai/karyawan suatu organisasi/perusahaan untuk bertindak dan berperilaku inovatif dan mencari prestasi kerja yang maksimal sesuai kemampuan dan keahlian yang dimilikinya. Sebaliknya, sistem imbalan yang didasarkan atas senioritas dan pilih kasih, akan berakibat tenaga kerja yang punya kemampuan dan keahlian dapat berlaku pasif dan frustasi. Kondisi semacam ini dapat berakibat kinerja organisasi/perusahaan menjadi terhambat.

9. Toleransi terhadap konflik, dimaksudkan sejauh mana para pegawai/karyawan didorong untuk mengemukakan konflik di mana kritik secara terbuka. Perbedaan pendapat merupakan fenomena yang sering terjadi dalam suatu organisasi/perusahaan. Namun, perbedaan pendapat atau kritik yang terjadi bisa dijadikan sebagai media untuk melakukan perbaikan atau perubahan strategi untuk mencapai tujuan suatu organisasi/perusahaan.

10. Pola komunikasi, dimaksudkan sejauh mana komunikasi dibatasi oleh hierarki kewenangan yang formal. Kadang-kadang hierarki kewenangan dapat menghambat terjadinya pola komunikasi antara atasan dan bawahan atau antar karyawan itu sendiri.

Kinerja merupakan terjemahan dari bahasa Inggris, work performance atau job performance tetapi dalam bahasa Inggris sering disingkat menjadi performance saja. Dalam bahasa Indonesia disebut juga prestasi kerja. Kinerja pada dasarnya adalah apa yang dilakukan atau tidak dilakukan karyawan (Hasibuan, 2007). Kinerja organisasi atau kinerja perusahaan merupakan indikator tingkatan prestasi yang dapat dicapai dan mencerminkan keberhasilan manajer/pengusaha.
Kinerja karyawan yang dinyatakan Mangkunegara (2005:55) adalah hasil kerja secara kualitas dan kuantitas yang dicapai oleh seseorang karyawan dalam melaksanakan tugasnya sesuai dengan tanggung jawab yang diberikan kepadanya. Oleh karena itu, output baik kualitas maupun kuantitas yang dicapai SDM persatuan periode waktu dalam melaksanakan tugas kerjanya sesuai dengan tanggung jawab yang diberikan kepadanya.

Masalah kinerja selalu mendapat perhatian dalam manajemen karena sangat berkaitan dengan produktivitas lembaga atau organisasi. Kinerja karyawan adalah yang mempengaruhi seberapa banyak mereka memberi kontribusi kepada organisasi yang antara lain termasuk: kuantitas output, kualitas output, jangka waktu output, kehadiran di tempat kerja, dan sikap kooperatif. Tampaknya dimensi lain dari Kinerja mungkin tepat untuk pekerjaan-pekerjaan tertentu, tetapi yang didata ini adalah yang paling umum, yang mengidentifikasikan elemen-elemen yang paling penting suatu pekerjaan.

Pekerjaan hampir selalu memiliki lebih dari satu kriteria atau dimensi untuk dinilai, dan ini berarti bahwa si karyawan mungkin berkinerja lebih baik dalam satu kriteria dibandingkan kriteria lainnya. Beberapa kriteria mungkin memiliki nilai lebih penting daripada kriteria lainnya. Pembobotan adalah suatu cara untuk menunjukkan hal ini. Beberapa perkantoran atau dinas lainnya merupakan bagian pekerjaan yang memiliki bobot yang lebih besar dibandingkan dengan penelitian atau pengabdian.

Pada saat mengukur kinerja, penting menentukan kriteria yang relevan, Umumnya, kriteria itu relevan ketika difokuskan pada aspek yang paling penting dari pekerjaan si karyawan. Sebagai contoh, menilai seorang petugas pelayanan kepuasan konsumen dalam suatu perusahaan dari .penampilan. tentu saja kurang relevan dibandingkan dengan jumlah telepon yang ditanganinya. Contoh ini menekankan bahwa kriteria pekerjaan yang terpenting harus diidentifikasikan dan dikaitkan dengan job description, job specification.

Pekerjaan umumnya melibatkan beberapa tugas dan tanggung jawab. Jika penilaian kinerja mengabaikan beberapa tanggung ja- 
wab yang penting, maka penilaian menjadi tidak efisien. Sebagai contoh, jika kinerja seseorang pewawancara hanya dinilai dari jumlah pelamar yang dipekerjakan, dan bukannya kualitas pelamar, maka hal ini bisa jadi tidak efisien. Jika beberapa kriteria yang tidak relevan dimasukkan, maka kriteria ini bisa dikatakan terkontaminasi.

Dharma (2005:355) mengatakan hampir semua cara pengukuran kinerja mempertimbangkan beberapa hal. Pertama, kuantitas, yaitu jumlah yang harus diselesaikan atau dicapai. Pengukuran kuantitatif melibatkan perhitungan keluaran dari proses atau pelaksanaan kegiatan. Kedua, kualitas, yaitu mutu yang harus dihasilkan (baik-tidaknya). Ketiga, ketepatan waktu yaitu sesuai tidaknya dengan waktu yang direncanakan. Pengukuran ketepatan waktu merupakan khusus dari pengukuran kuantitatif yang menentukan ketepatan waktu penyelesaian pekerjaan.

Menurut Hasibuan (2007:56), kinerja dapat dikatakan baik atau dapat dinilai dari beberapa hal, antara lain: (1) kesetiaan, (2) prestasi kerja, (3) kedisiplinan, (4) kreativitas, (5) kerjasama, (6) kecakapan, (7) tanggung jawab, (8) efektifitas dan efisiensi

Kesetiaan pegawai dapat dilihat dari tekad dan kesanggupan menaati, melaksanakan dan mengamalkan sesuatu yang ditaati dengan penuh kesadaran dan tanggung jawab, sehingga menghasilkan prestasi kerja yang maksimal. Prestasi kerja merupakan kinerja yang dicapai oleh seorang pegawai dalam melaksanakan tugas dan pekerjaan yang diberikan kepadanya.

Kinerja pegawai dinilai berdasarkan kedisiplinannya dalam menjalankan tugasnya sebagai pegawai yaitu kesadaran dan kesediaan seorang pegawai untuk menghormati, menghargai, mematuhi dan menaati peraturan-peraturan yang berlaku, baik yang tertulis maupun tidak tertulis serta sanggup menjalankannya.

Selain itu, kreativitas pegawai juga perlu dibangun. Kreativitas ini berupa kemampuan pengetahuan yang dimiliki karyawan dan juga kemampuan untuk mengemukakan atau menciptakan suatu program kerja baru dalam menghadapi tantangan kerja, baik secara individu maupun dalam tim, sehingga pegawai juga dituntut untuk mempunyai kemampuan bekerjasama dengan orang lain dalam menyelesaikan suatu tugas dan pekerjaan yang telah ditetapkan, sehingga mencapai daya guna dan hasil guna yang sebesar-besarnya. Pekerjaan yang dilakukan pegawai harus berjalan secara efektif dan efisien agar dapat meningkatkan kinerjanya. Yang terpenting dalam menyelesaikan tugas dan pekerjaan tersebut adalah karyawan mempunyai kesanggupan untuk menyelesaikan dengan sebaik-baiknya dan tepat waktu sert berani memikul risiko atas keputusan yang telah diambilnya.

\section{Metode Penelitian}

Menurut Sugiyono, (2006:87) Populasi adalah wilayah generalisasi yang terdiri atas obyek/subyek yang mempunyai kualitas dan karakteristik tertentu yang ditetapkan untuk dipelajari dan kemudian ditarik kesimpulannya. Populasi dalam penelitian ini adalah seluruh pegawai Kantor Kementerian Agama Kota Banjarbaru yang berjumlah 164 orang.

Adapun pengambilan sampel dilakukan dengan secara acak atau sampel random sampling. Pegawai yang dijadi-kan sampel yaitu sebanyak 116 pegawai.

Analisis yang digunakan dalam penelitian ini adalah analisis kuantitatif yaitu dengan menggunakan model regresi linier berganda (multiple linier regression method). Bentuk rumusan matematik dari analisis regresi linier berganda yang dipergunakan untuk mengetahui pengaruh variabel bebas yaitu mutasi, promosi dan budaya organisasi terhadap variabel terikat yaitu kinerja pegawai adalah sebagai berikut ini :

$$
Y=a+b_{1} X_{1}+b_{2} X_{2}+e
$$

\section{Keterangan :}

$$
\begin{array}{ll}
\mathrm{Y} & =\text { Kinerja } \\
\beta 0 & =\text { Konstanta (intersep) } \\
\beta 1 . . \beta 5 & =\text { Koefisien regresi } \\
\mathrm{X} 1 & =\text { Mutasi } \\
\mathrm{X} 2 & =\text { Promosi } \\
\mathrm{X} 3 & =\text { Budaya Organisasi } \\
\varepsilon & =\text { Kesalahan pengganggu }
\end{array}
$$

\section{Hasil Penelitian dan Pembahasan}


Dari variabel mutasi $\left(\mathrm{X}_{1}\right)$, pada item pertanyaan $\mathrm{X}_{1.1}$ sebanyak 45 orang $(40,5 \%)$ menjawab sangat setuju; pada item pertanyaan $\mathrm{X}_{1.2}$ sebanyak 43 orang $(37,1 \%)$ menjawab sangat setuju; pada item pertanyaan $\mathrm{X}_{1.3}$ sebanyak 48 orang $(41,1 \%)$ menjawab sangat setuju; pada item pertanyaan $\mathrm{X}_{1.4}$ sebanyak 70 orang $(60,3 \%)$ menjawab sangat setuju; pada item pertanyaan $\mathrm{X}_{1.5}$ sebanyak 70 orang $(60,3 \%)$ menjawab sangat setuju; pada item pertanyaan $\mathrm{X}_{1.6}$ sebanyak 56 orang $(48,3 \%)$ menjawab sangat setuju; dan pada item pertanyaan $\mathrm{X}_{1.7}$ sebanyak 56 orang $(48,3 \%)$ menjawab sangat setuju.

Dari variabel promosi $\left(\mathrm{X}_{2}\right)$, pada item pertanyaan $\mathrm{X}_{2.1}$ sebanyak 54 orang $(46,6 \%)$ menjawab sangat setuju, pada item pertanyaan $\mathrm{X}_{2.2}$ sebanyak 60 orang $(51,7 \%)$ menjawab sangat setuju; pada item pertanyaan $\mathrm{X}_{2.3}$ sebanyak 64 orang $(55,2 \%)$ menjawab sangat setuju; pada item pertanyaan $\left(\mathrm{X}_{2.4}\right)$ sebanyak 62 orang $(53,3 \%)$ menjawab sangat setuju; pada item pertanyaan $\left(\mathrm{X}_{2.5}\right)$ sebanyak 60 orang $(51,7 \%)$ menjawab sangat setuju, pada item pertanyaan $\left(\mathrm{X}_{2.6}\right)$ sebanyak 69 orang $(59,5 \%)$ menjawab sangat setuju; pada item pertanyaan $\left(\mathrm{X}_{2.7}\right)$ sebanyak 59 orang $(50,9 \%)$ menjawab sangat setuju; pada item pertanyaan $\left(\mathrm{X}_{2.8}\right)$ sebanyak 62 orang $(53,4 \%)$ menjawab sangat setuju; dan pada item pertanyaan $\left(\mathrm{X}_{2.9}\right)$ sebanyak 57 orang $(49,1 \%)$ menjawab sangat setuju.

Dari variabel budaya organisasi $\left(\mathrm{X}_{3}\right)$, pada item pertanyaan $\left(\mathrm{X}_{3.1}\right)$ sebanyak 48 orang $(41,4 \%)$ menjawab setuju; pada item pertanyaan $\left(\mathrm{X}_{3.2}\right)$ sebanyak 50 orang $(43,1 \%)$ menjawab sangat setuju; pada item pertanyaan $\left(\mathrm{X}_{3.3}\right)$ sebanyak 60 orang $(51,7 \%)$ menjawab sangat setuju; pada item pertanyaan $\left(\mathrm{X}_{3.4}\right)$ sebanyak 45 orang $(38,8 \%)$ menjawab sangat setuju; pada item pertanyaan $\left(\mathrm{X}_{3.5}\right)$ sebanyak 45 orang $(38,8 \%)$ menjawab sangat setuju; dan pada item pertanyaan $\left(\mathrm{X}_{3.6}\right)$ sebanyak 54 orang $(46,6 \%)$ menjawab sangat setuju.

Dari variabel kinerja (Y), pada item pertanyaan $\left(\mathrm{Y}_{1}\right)$ sebanyak 47 orang $(40,5 \%)$ menjawab setuju; pada item pertanyaan $\left(\mathrm{Y}_{2}\right)$ sebanyak 53 orang $(45,7 \%)$ menjawab sangat setuju; pada item pertanyaan $\left(\mathrm{Y}_{3}\right)$ sebanyak 48 orang $(41,4 \%)$ menjawab sangat setuju; pada item pertanyaan $\left(\mathrm{Y}_{4}\right)$ sebanyak 45 orang
$(38,8 \%)$ menjawab sangat tidak setuju; pada item pertanyaan $\left(\mathrm{Y}_{5}\right)$ sebanyak 53 orang $(45,7 \%)$ menjawab sangat setuju; pada item pertanyaan $\left(\mathrm{Y}_{6}\right)$ sebanyak 52 orang $(44,8 \%)$ menjawab sangat setuju, pada item pertanyaan $\left(\mathrm{Y}_{7}\right)$ sebanyak 60 orang $(51,7 \%)$ menjawab sangat setuju; dan pada item pertanyaan $\left(\mathrm{Y}_{8}\right)$ sebanyak 61 orang $(52,6 \%)$ menjawab sangat setuju.

Hasil uji hipotesis I menunjukkan bahwa variabel mutasi $\left(\mathrm{X}_{1}\right)$ berpengaruh terhadap kinerja $(\mathrm{Y})$, di mana variabel mutasi $\left(\mathrm{X}_{1}\right)$ memiliki nilai probabilitas signifikansi yaitu $0,000<0,05$. Hasil uji hipotesis II menunjukkan bahwa variabel promosi $\left(\mathrm{X}_{2}\right)$ berpengaruh terhadap kinerja $(\mathrm{Y})$, di mana variabel promosi $\left(\mathrm{X}_{2}\right)$ memiliki nilai probabilitas signifikansi yaitu $0,000<0,05$. Hasil uji hipotesis III menunjukkan bahwa budaya organisasi $\left(\mathrm{X}_{3}\right)$ berpengaruh terhadap kinerja $(\mathrm{Y})$, di mana variabel budaya organisasi $\left(\mathrm{X}_{3}\right)$ memiliki nilai probabilitas signifikansi yaitu $0,000<0,05$. Hasil uji hipotesis IV menunjukkan nilai signifikansi $F_{\text {hitung }}$ adalah 0,000 $<0,05$, sehingga hipotesis keempat yang mengatakan mutasi, promosi dan budaya organisasi berpengaruh signifikan secara simultan terhadap kinerja dapat diterima atau teruji.

Hasil penelitian menunjukkan bahwa di lingkungan Kementrian Agama Kota Banjarbaru, variabel mutasi, promosi, dan budaya organisasi memiliki pengaruh yang signifikan terhadap kinerja. Untuk dapat meningkatkan kinerja pegawainya, Kantor Kementrian Agama Kota Banjarbaru harus terus memperhatikan keadilan dan kesesuaian dari kebijakan-kebijakan yang dikeluarkannya, terutama kebijakan mengenai mutasi dan promosi jabatan. Kantor Kementrian Agama Kota Banjarbaru juga harus terus menjaga agar budaya organisasi di organisasi tersebut tetap berjalan dengan baik. Budaya organisasi yang bersifat positif harus terus dikomunikasikan kepada para pegawai, sehingga budaya itu dapat terus hidup dan tumbuh di Kantor Kementrian Agama Kota Banjarbaru, walaupun pegawainya sudah banyak berubah, baik karena mutasi maupun pensiun yang digantikan oleh pegawaipegawai baru. 


\section{Kesimpulan}

Berdasarkan pada pembahasan yang telah dikemukakan sebelumnya, maka dapat dirumuskan kesimpulan dari penelitian ini, yaitu sebagau berikut :

1. Variabel mutasi memiliki pengaruh yang signifikan terhadap kinerja pegawai Kementerian Agama Kota Banjarbaru.

2. Variabel promosi memiliki pengaruh yang signifikan terhadap kinerja pegawai Kementerian Agama Kota Banjarbaru.

3. Variabel budaya organisasi memiliki pengaruh yang signifikan terhadap kinerja pegawai Kementerian Agama Kota Banjarbaru.

4. Variabel mutasi, promosi dan budaya organisasi, secara simultan memiliki pengaruh yang signifikan terhadap kinerja pegawai Kemen-terian Agama Kota Banjarbaru.

\section{DAFTAR PUSTAKA}

Armstrong Michael, 2005, Manajemen Sumber Daya Manusia, Elex Media Komputindo, Jakarta.

Dharma Surya, 2005, Manajemen Kinerja, Edisi Ketiga, Pustaka Pelajar, Yogyakarta.

Gibson James L., 2005, Perilaku Organisasi, Rineka Cipta, Jakarta.

Gomes Faustino Cardoso, 2008, Manajemen Sumber Daya Manusia, Andi, Yogyakarta.

Hasibuan H. Malayu S.P., 2007, Manajemen: Dasar, Pengertian, dan Masalah, Edisi Revisi, Bumi Aksara, Jakarta.

Hofstede Geert, 2007, Cultures and Organizations: Software of the Mind, McGraw-Hill, New York.
Mangkunegara Anwar Prabu, 2005, Evaluasi Kinerja Sumber Daya Manusia, Refika Aditama, Jakarta.

Moekijat, 2005. Kamus Manajemen, Statistik dan Pendidikan, Pustaka Setia, Bandung.

Nitisemito Alex. S., 2005, Manajemen Personalia, Edisi Revisi, Ghalia Indonesia, Jakarta.

Rivai Veithzal, 2005, Manajemen Sumber Daya Manusia untuk Perusahaan dari. Teori ke Praktik, Raja Grafindo Persada, Jakarta.

Robbins Stephen P, 2006, Prinsip-prinsip Perilaku Organisasi, Edisi Kelima, Erlangga, Jakarta.

Sastrohadiwiryo Siswanto, 2008, Manajemen Tenaga Kerja Indonesia, Edisi Kedua, Bumi Aksara, Jakarta.

Saydam Gauzali. 2005, Manajemen Sumber Daya Manusia, Edisi Kedua, Toko Gunung Agung, Jakarta.

Sedarmayanti, 2005, Manajemen Sumber Daya Manusia, Ilham Jaya, Bandung.

Simamora Henry, 2006, Manajemen Sumber Daya Manusia, Edisi 2, STIE YKPN, Yogyakarta.

Soetjipto, 2007, Budaya Organisasi, Gramedia, Jakarta.

Sugiyono, 2006, Metode Penelitian Kuantitatif Kualitatif dan $R \& D$, Alfabeta, Bandung.

Susanto, 2007, Leadpreneurship, Erlangga, Jakarta.

Suwatno, .2007, Asas-asas Manajemen Sumber Daya Manusia, Suci Press, Bandung. 